\title{
A Probabilistic Domain-knowledge Framework for Nosocomial Infection Risk Estimation of Communicable Viral Diseases in Healthcare Personnel: A Case Study for COVID-19
}

This paper was downloaded from TechRxiv (https://www.techrxiv.org).

\section{LICENSE}

CC BY 4.0

SUBMISSION DATE / POSTED DATE

$06-11-2021 / 11-11-2021$

\section{CITATION}

Huynh, Phat (2021): A Probabilistic Domain-knowledge Framework for Nosocomial Infection Risk Estimation of Communicable Viral Diseases in Healthcare Personnel: A Case Study for COVID-19. TechRxiv. Preprint. https://doi.org/10.36227/techrxiv.16943434.v1

$\mathrm{DOI}$ 
TABLE 1S

CHARACTERISTICS OF THE SELECTED FEATURES AND THEIR ASSOCIATED DATABASES

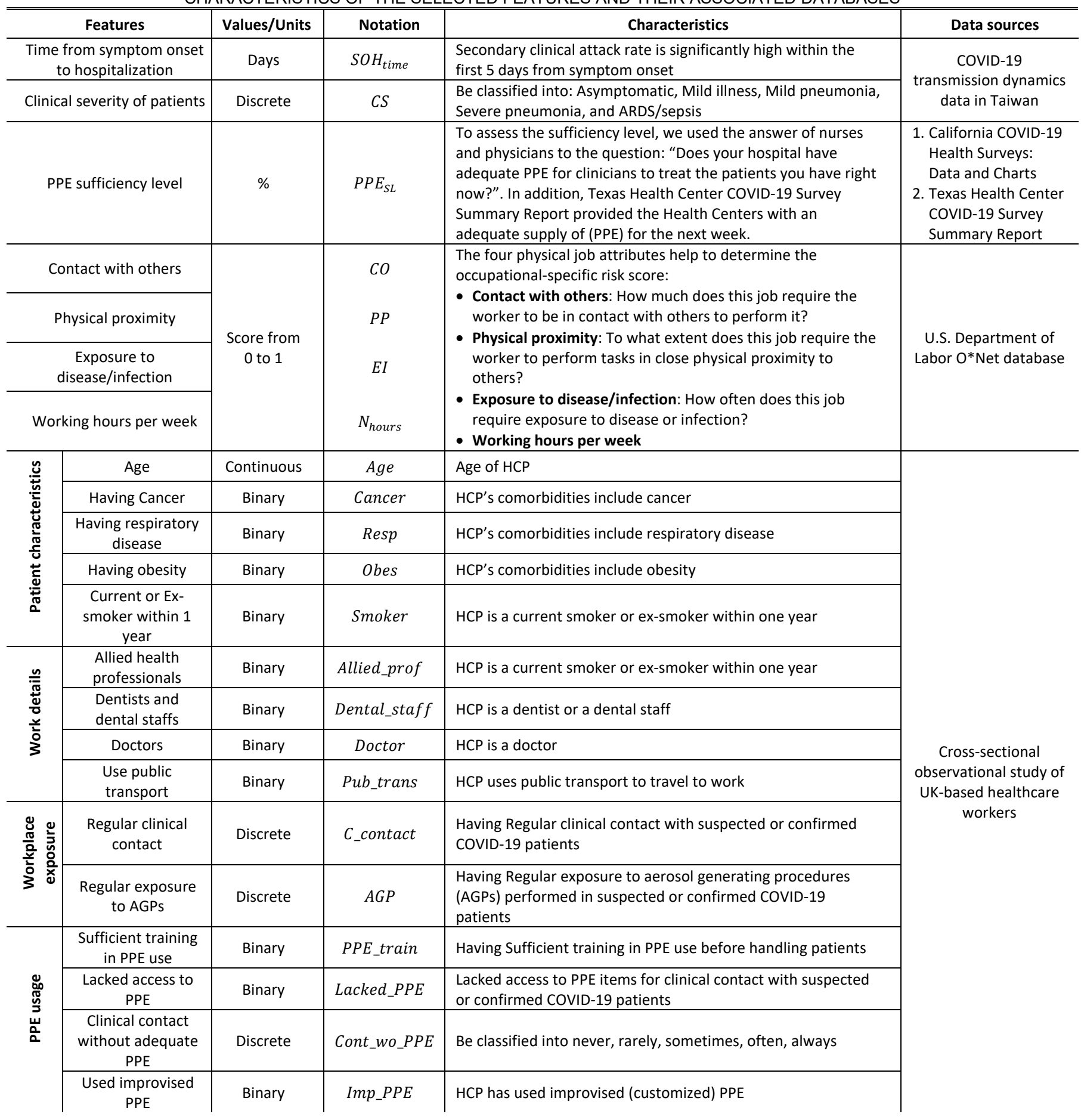

